\title{
The Yukon district
}

\section{Wm. Ogilvie}

To cite this article: Wm. Ogilvie (1898) The Yukon district, Scottish Geographical Magazine, 14:7, 337-346, DOI: 10.1080/00369229808733002

To link to this article: http://dx.doi.org/10.1080/00369229808733002

册 Published online: 27 Feb 2008.

Submit your article to this journal

LII Article views: 6

Q View related articles $\asymp$ 


\title{
THE SCOTTISH
}

\section{GE O G R A P H C A L}

\author{
MAGAZINE.
}

\section{THE YUKON DISTRICT.}

By Wm. OGILvie, Astronomer and Dominion Land Surveyor.

\author{
(With a Map.)
}

IN north longitude $59^{\circ} 46^{\prime}$ approximately, west longitude $135^{\circ} 13^{\prime}$, the first trickling streams which unite to form the head of the Lewes branch of the Yukon begin. They converge into a small lake in a deep mountain valley, snow-clad for nearly ten months in the year, less than fifteen miles from which, as the crow flies, in a southerly direction, is the head of Dyea inlet - the most easterly arm of Lynn canal. Out of this lake, known as Summit lake, these waters flow down a turbulent mountain stream, less than half a mile in length, into another smaller lake known as Crater lake, from its resemblance to a crater. This lake pours its waters through a still more turbulent stream into another lake much more extensive, called Long,lake, and this again through a short link into Lower lake, which discharges its waters through the cañon into Lake Lindeman. The fall between the two latter lakes is nearly 1000 feet, in an interval of less than three miles. Lake Lindeman is about five miles in length, and its waters discharge by a stream less than a mile in length, which, however, is impassable for ordinary boats owing to bad rapids in the middle, into Lake Bennett. At the head of Lake Bennett we are on the navigable waters of this stream. It is upwards of twentyfive miles in length. At its foot is a small lake known as Cariboo crossing, because it was a favourite place for those animals to cross in their migrations from the south to the north, and on their return. This is connected with Tagish lake by a short, crooked stream, less than 200 yards in length. Tagish lake is about seventeen miles in length, on the route followed by the miners to the Lewes; but extends southwards from the travelled way nearly thirty miles, aggregating in all its arms a consider-

voL. XIV. 
able body of water. Out of Tagish lake we go through a short stream named Tagish river, after the Indians of that locality who used to make it their winter quarters; several of their wooden houses are now standing on its banks. This point has been selected by the Dominion Government for a police station and customs office; and here all miners and others entering the country by this route are stopped, their goods examined, and customs dues exacted on all foreign goods. The stream is about five miles in length, and nowhere less than 100 yards in width. The shallowest part in it is about six feet deep at ordinary stages of water-this only for. a short distance near its head. All the rest is twelve feet and upwards. About four miles below the police post we reach Marsh lake, nineteen miles in length, affording good deep water everywhere. Marsh lake averages about one to one and a-half miles in width, and during a high wind becomes pretty rough, as do Tagish and Bennett lakes. On the river twenty-five and a-half miles below Marsh lake we reach the Cañon, and two and a-half miles below this, White Horse rapids. In this series of rapids there is a fall of upwards of thirty feet, about ten of which are in the Cañon within less than five-eighths of a mile, six or seven in the rapids intervening between the Cañon and the White Horse. in about a fourth of a mile, and the remainder, of fifteen or sixteen feet, in White Horse rapids in less than half a mile. These rapids are impassable for steamers, and past them a tramway or some other mode of conveyance will have to be constructed for all materials entering the country by this route. This will prove a serious hindrance to transit by this route for all time. Steamers capable of navigating the lakes mentioned in all weathers may prove a little too deep in draught for the river between the foot of Marsh lake and the Cañon; but admitting that they do not, arrived at the head of the Cañon they will have to discharge their cargo, which will have to be conveyed over a tramway or other means of conveyance to the foot of the White Horse, and.reloaded on to another river steamer, which will make its way down stream from there as far as may be necessary, without any difficulty.

Twenty-seven miles below White Horse rapids we reach Lake Labarge, a lake upwards of thirty-one miles in length. The upper part of it averages between three and four miles in width, and the lower half nearly two miles. Here, again, river steamers of light draught may be detained by high winds, as a strong wind in a very few hours lashes the water into a very rough state, and of course river steamers of shallow draught have not the necessary depth and stiffness to navigate such waters. Thirtyone miles, or a little more, below Lake Labarge, we reach the mouth of the Teslin, a branch of the Yukon, which is commonly known to the miners, and in fact to all in that country, as the Hootalinqua.

From this point we will now go back and describe the Teslin route. It begins properly at Fort Wrangel, near the mouth of the Stikine river. This post is in American territory, and hindrances may, and no doubt will, be put in the way of the transfer of Canadian or British cargoes from British ocean ships to British river steamers at Wrangel. Should these hindrances be made too troublesome, British ships can discharge their cargo at Fort Simpson in British waters, about 170 miles farther south. 


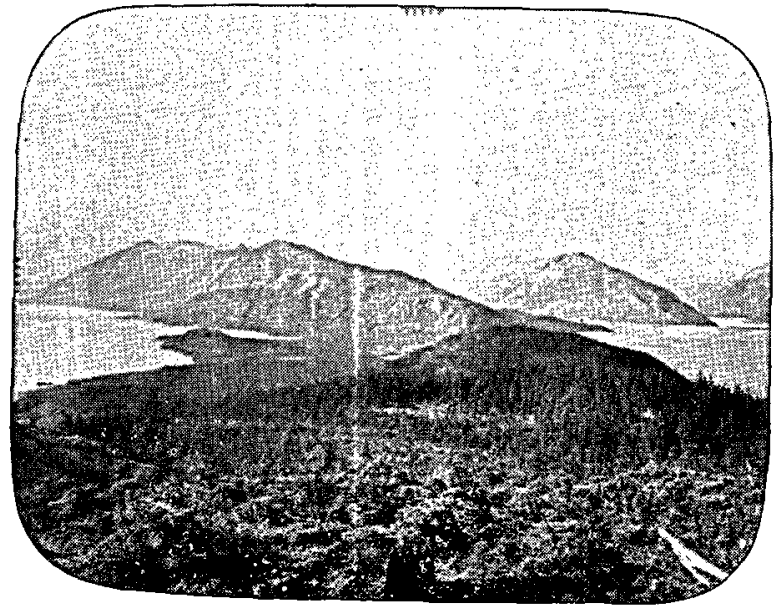

LOOKING UP THE CHILKAT AND CHILKOOT INLETS AND THE DYEA SANKA FROM NEAR POINT SEDUCTIOX.

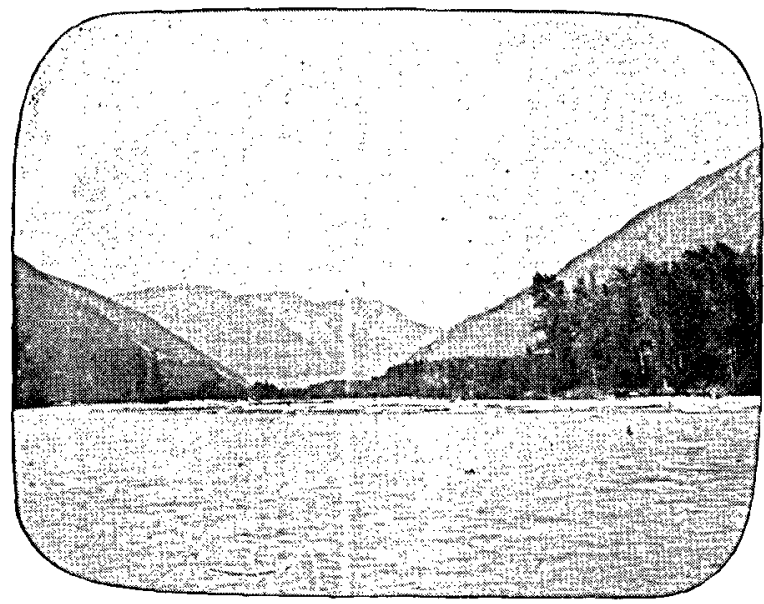

LOOKING UP THE DYEA PASS. 


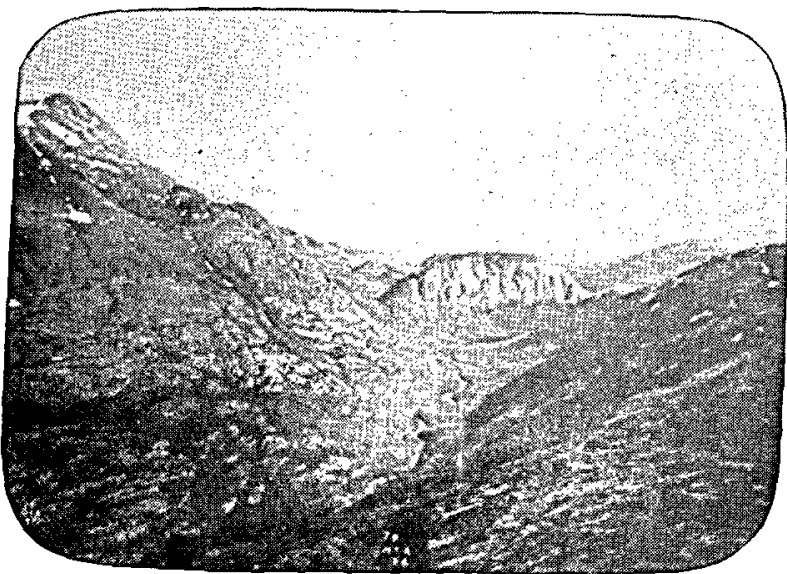

LOOKING UP WHITE PASS FROM BELOW FORKS,

(Summit of Pass on left of high riage in centre.)

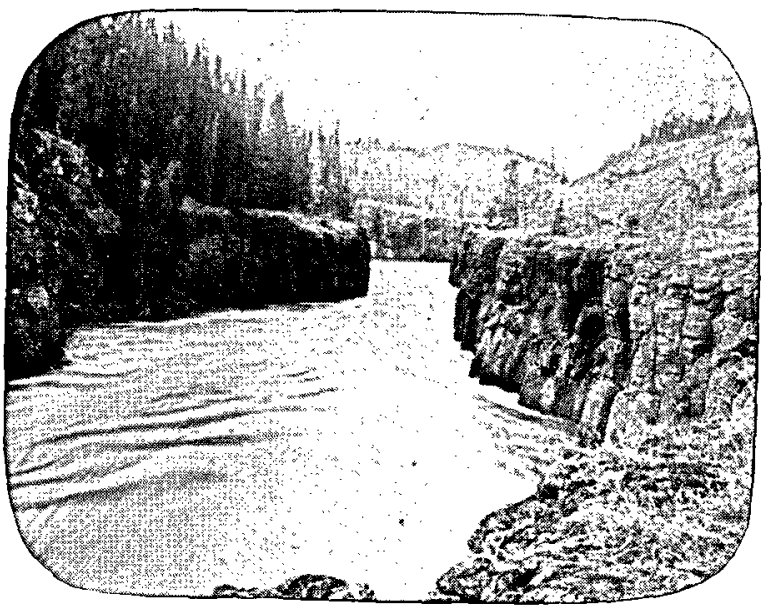

LOOKIYG DOWN CAÑON.

(95 miles from heoul of Lalie Dennett.) 
River steamers can, in fine weather, easily make their way from Simpson to and past Wrangel into the Stikine river, traversing on it the narrow strip of territory belonging to the United States along the coast, and as Britain, in the treaty with Russia in 1825 defining the boundary between British and Russian territory, secured the right of free navigation of all streams, inlets, and bays leading from the interior to the waters of the ocean, and again in the treaty between the United States and Great Britain in 1870 this was accentuated by specialising the Stikine river, the free navigation of which was secured to Great Britain and her dependencies in the treaty-it is presumed that the United States cannot possibly raise any objection or put any hindrance in the way of a steamer clearing at Fort Simpson and passing on to Telegraph creek in British territory on the Stikine river.

From Fort Wrangel to Telegraph creek is 150 miles. River steamers have navigated that stream since the early seventies, when considerable mining was done in the northern part of the province of British Columbia in the district known as the Cassiar district. Since that time a small steamer, the Alaska, has been almost continuously plying on the river, carrying goods for the few traders doing business in that country. In -1896 and 1897 the Hudson Bay Company's steamer Caledonian made four trips, two in each of those years, from Fort Simpson up the Stikine river to Telegraph creek. This steamer draws, when loaded, four feet of water, and on none of these occasions did she meet with any serious inconvenience, except perhaps once when a very heavy rain raised the water in the river so high that immense quantities of driftwood came down, and she had to tie up in a sheltered place until the bulk of it had passed. The only trouble the steamer experienced in the passage was across Dixon's Entrance, which begins immediately at Simpson, and continues for upwards of forty miles to Mary Island. Through Dixon's Entrance from the Pacific Ocean the swell in a storm blows landward, and of course precludes the possibility of an ordinary river steamer crossing during its continuance. This would necessitate a delay, as the steamers would have to abide the event of the weather, and await a favourable opportunity to cross, which could be done in about four hours. When the wind blows from the land there is not so much trouble. As this steamer has made four trips successfully, it may reasonably be argued that other steamers can do the same. Had it been necessary to make more than two trips each season, she could have done so with reasonable security, but that was all that was required of her, and she successfully accomplished it. Her time from Simpson to Fort Wrangel was about seventeen hours, and from Wrangel to Telegraph creek the voyage occupied the bulk of three days, but her actual running time was somewhere about forty hours. The balance was taken up in cutting and loading wood, and tying up at night, unloading freight and passengers, and taking others on again. It was the intention of the Canadian Government to construct a railway from Telegraph creek to Teslin lake, out of which the river already mentioned as the Teslin or Hootalinqua flows into the Lewes. This railway. would be about 150 miles. in length, and examinations of that piece of 
country have shown that there is nothing very serious in the way to prevent construction. The contract was let, and ratified by the House of Commons in Canada, but rejected by the Senate, and it remains to be seen what further action will be taken in the matter. But there is no doubt that a road will soon be constructed between those two points. There is also very little doubt that this road will be continued southwards through the heart of British Columbia, traversing on its way a region part of which is known to be fairly rich in minerals, and will ultimately connect with the Canadian Pacific; and it can be reasonably predicted that it will be a fairly remunerative line, seeing that it. will pass through mineral, grazing, and timber country.

Another path, from the head of the Chilkat arm of Lynn canal, is known as the Dalton route. This for upwards of 240 miles is all land travel. Examination has shown that it passes over gently undulating country, where a road would not be difficult of construction. ' It would also obviate the necessity of transferring the cargo at the rapids mentioned, and avoid delay from rough water on the lakes, by striking the river below the Five Finger rapids, from which point easy navigation. obtains down to the boundary line, and beyond it into the Yukon Flats.

The Yukon Flats are about 100 miles in length. In this length the river expands to five, six, and maybe ten miles in width. It is evident that there was at one time a great lake in this stretch of the river, but it has been filled up by silt and drift to such an extent that it is now dotted with numberless islands, and divided into various intricate and narrow channels. These channels are almost continuously changing their depth and direction, so that navigation is at several points very difficult and uncertain. A steamboat may pass up or down easily on one trip, and on her succeeding one come to grief on some bar or the point of some island. This has occurred very often, and in fact was the cause of the threatened starvation at Dawson last winter. In seasons in which the. water remains high, little difficulty is experienced here, but in low water this section is simply impassable. After August 1897, no boat navigating the stream could pass one of the points in these flats. The result was that provisions intended for Dawson were detained here for weeks; only two steamers passed it-one with a cargo of about seventy-two tons, and the other with forty-six tons. Their full complement would be about 250 and 300 tons. These flats once passed, there is no further difficulty for about 900 miles, when the river again spreads out into many channels, but the islands are larger and the channels wider. In low water a little difficulty is experienced here at times through missing the right channel, and some search to find a way for the steamer may be necessary. Arrived at the mouth, we again encounter shoal water and crooked channels, which are difficult of navigation, and require the experience of old local pilots, generally Indians. Here, too, the steamers are often detained for days by storms on Bering Sea. From the mouth of the channel steamboats navigate to Fort St. Michael, the emporium for all that district, where the ocean steamers discharge cargo, a distance of about seventy miles; and of course in rough weather river steamboats cannot cross it. The result is that steamers making their way to St. Michael, and also from it, 
are often delayed for many days. All these conditions combine to make it tolerably certain that not more than one trip per month can be made by any of the steamers now running - and some of them are fairly good ones-from St. Michael to Dawson. Bering Sea, as a rule, is not open for navigation until towards the first of July. The last ten days in June may be defined as the earliest period in which ships can approach St. Michael-in some cases it has been retarded till well into July. In 1896, the seventh of July was the date of the first arrival at St. Michael of a steamer. As the Yukon river begins running ice in the. middle of October, and steamers run some risk after the end of September, we can thus only count on three to three and ahalf months for navigation by this route-that is the ocean and river route.

With a railway between Telegraph creek, or any other point on the Stikine river, to the head of Teslin lake, we are assured of about five months' navigation in the year, with the important advantage that loaded steamers make their way down the stream four or five or six hundred miles, as it may be, instead of up stream fifteen, sixteen, or seventeen hundred-a very important difference. By this way the same steamers could make three trips for one as compared. with the St. Michael route; and as the Yukon would remain navigable for about the same length of time as the Stikine, this undoubtedly is the route to be opened for the due and proper development of the Yukon district. The Teslin route also obviates the detention and transfer of cargo at the Cañon and White Horse rapids, as a steamer loading at the head of Teslin lake meets no hindrance or stoppage until she arrives at her destination. Possibly a storm on Teslin lake, which is sixty-five miles in length, might detain her, as steamers on the lakes on the other route would be detained; but Teslin lake is not so wide as Labarge, and shelter is afforded along its length at various points,' so that it is highly probable the same hindrance to passage will not be offered here as on Labarge.

The other routes to the country need hardly be discussed at present. Just now the Dyea route and the White Pass route-they are so close together as to be practically the same-take the attention of the great bulk of the miners attempting entrance. With a good road over the Teslin route, it may be said that it will absorb seventy-five per cent. of the traffic, if indeed not all. No other route at present spoken of, except the ocean and river route, can at all compare with these, either in time, cost, or comfort.

Gold was known to exist in the Yukon country as early as 1847, for Robert Campbell, who built the Hudson Bay Company trading-post at the confluence of the Pelly and Lewes, found it in small quantities in the gravel of the beach at that point. Gold-mining, however, was not his business, and he paid little or no attention to it.

Some time early in the sixth decade of the present century, a Canadian missionary-now the venerable Archdeacon Macdonald of Fort Macpherson, in the delta of the Mackenzie river-found it at the head of Birch creek, a tributary of the Yukon, which joins it near the Arctic circle in west longitude $146^{\circ}$ approximately. This discovery led to the 
establishment of the Birch creek diggings and the trading-port known as Circle City, in north latitude $65^{\circ} 40^{\prime}$ approximately, and west longitude $144^{\circ}$.

Mr. Arthur Harper and his associates made their way from the head of Peace river, in the heart of British Columbia, in September 1872, to the vicinity of Fort St. John, on the upper Peace. Thence they crossed the watershed between the Peace and Liard rivers to a branch of the latter known as the Nelson, down which they went to the Liard, down it to the Mackenzie, and down it to the Hudson Bay Company's portage or route between the waters of the Mackenzie and the Porcupine, a branch of the Yukon. They traversed this portage, ran down the Porcupine, and up the Yukon to White river, up which they went many miles prospecting. Harper summed up his experience in prospecting thus: "On the Nelson, nothing; on the Liard, prospects ; on the Mackenzie, nothing; at the mouth of the Peel, which has a common delta with the Mackenzie, good prospects; on the Porcupine, a little; and on the Yukon, gold everywhere we tried." His correspondence with friends whom he left behind led, to a considerable extent, to the resort of miners to that region; and mining on the Yukon may be stated to have begun shortly after that year.

In the early eighties mining was done in earnest along the banks of the Lewes and on the Stewart. The discovery of coarse gold on Forty- mile river in 1886 led to the abandonment of all other work in that country, as coarse gold has always been the great desideratum of miners. Fortymile continued to be worked by the vast majority of those entering the country, much against the will, however, of a good many of them, who would have far rather worked on Stewart river had they been able to obtain supplies there, but Fortymile received them all, until the diggings of Birch creek were established. Circle City, the emporium for Birch creek, and the town of Fortymile divided between them until 1896 all the provisions that could be taken into the country, and there was not enough to support the numbers then mining, a goodly percentage of whom had to make their way out each fall, live the winter in the cities along the western coast, and re-enter in the spring.

In 1896 gold was found in abundance in the world-renowned Klondike district. This led to the almost entire abandonment of the Circle City and Fortymile districts, and now, whether they will or no, the companies trading there have to deposit all their provisions at Dawson City, the emporium for the district.

As to the distribution of gold through the territory, it may be stated generally that gold is found pretty well all over the upper part of the Yukon basin, and in a good part of the lower end of it as well. The basin of the Yukon comprises within its bounds, as far as known, about 338,000 square miles of territory, with about 3200 miles of navigable river. Of this area nearly 150,000 miles, a little less than half, is British territory, and of the navigable stream over 1300 miles. The British end of it yields about 6000 miles of river, stream, and gulch. The other streams, not confluent to the Yukon, will increase this length to about 7000 miles. Now it may be said that almost everywhere in this area gold 


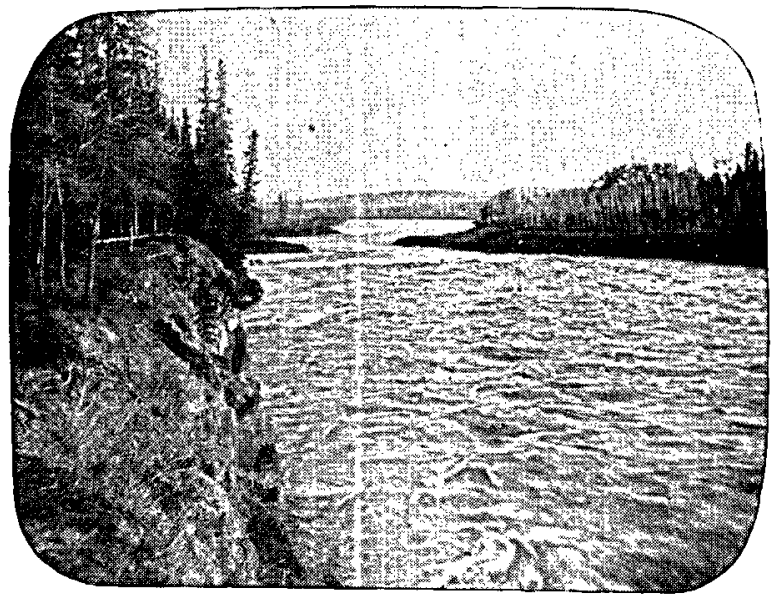

LOOKING DOWN WHITE HORSE RAPIDS.

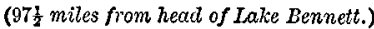

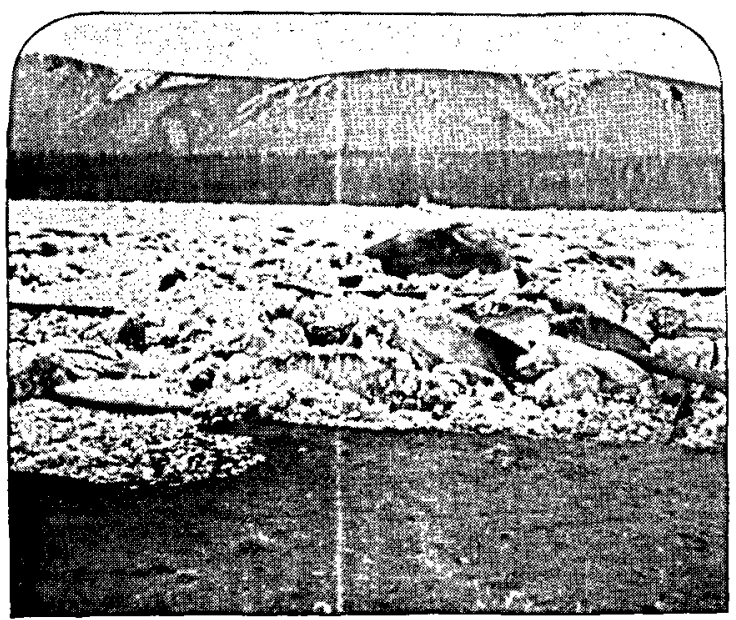

BREAK-LP OF ICE ON THE YUKON RIVER. 


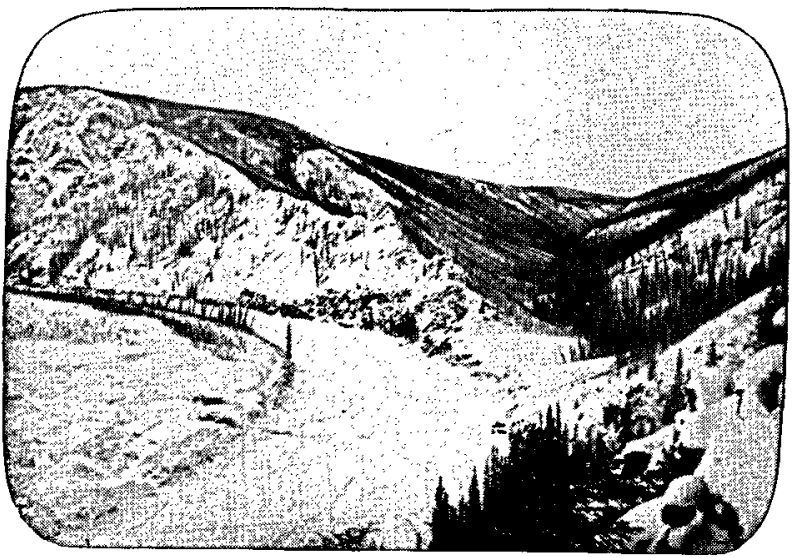

FORTY-MILE RIVER

(where the International Boundary crosses it)

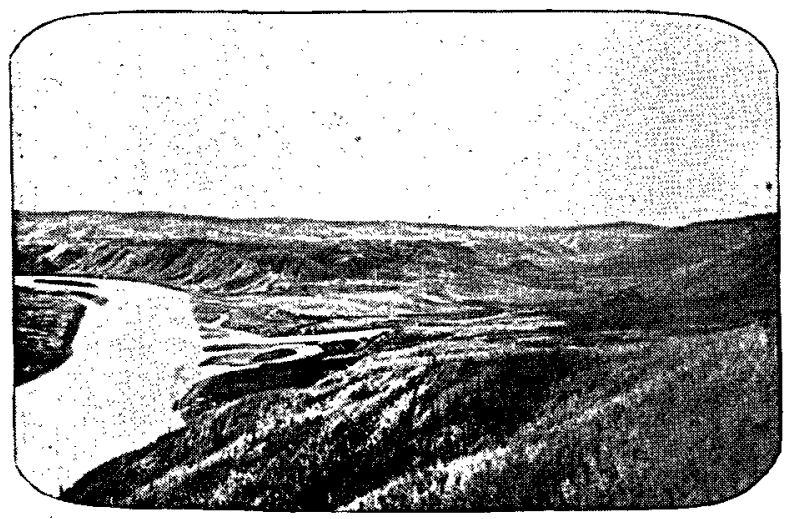

CONFLUENCE OF THE YUKON AND FORTY-MILE RIVERS.

(40 miles above International Boundary.) 
has been found where prospecting has been done-true, in some places in very limited quantities; but in many places in quantity sufficient to well reward individual effort. Others sites will not pay at present, but, under improved conditions of transport and reduced wages, will yield a fair income. To put it in another way-of these 7000 miles of river, stream, and gulch, we can safely assert that at least one-half yields gold. Much of it, we know, yields it in paying quantities. Of these 3500 miles, at present we know that only about 200 have been tested and developed, and, possibly, 400 or 500 located are in part tested. Indications point to rich diggings yet to be discovered. We cannot positively assert that they will be; neither can we deny it; but we can positively point to upwards of 3000 miles of stream and gulch which are likely to yield good returns to investors or individual effort. So much for placer or alluvial deposits of gold, which may be characterised as the individual's mine.

Gold-bearing rock, locally named quartz (we will not discuss its lithological character), has been discovered and located at some nine or ten points in the Fortymile and Klondike areas. Many of these lie close together. Nearly all of the reefs are very extensive, and all, with one exception, are low grade, yielding from $24 \mathrm{~s}$. to $25 \mathrm{~s}$. per ton to $45 \mathrm{~s}$. to $50 \mathrm{~s}$. per ton, averaging possibly $30 \mathrm{~s}$. to $35 \mathrm{~s}$. a ton. One of these is close to the mouth of Fortymile river, and is so extensive that it will take a goodly sized stampmill generations to exhaust it. Two other locations, about thirtyfive miles farther up the Yukon river, may be characterised in the same words. These three will possibly return between $30 \mathrm{~s}$. and $40 \mathrm{~s}$. to the ton of rock. The others have not yet been assayed; consequently we are unable to speak with any authority about them. One small exposure found on the bank of Hunker creek yielded, to a very crude assay, from 100 dollars $(£ 20)$ to 1000 dollars $(£ 200)$ per ton of rock. Unfortunately at present we are unable to say whether this is of sufficient extent to justify attempts at development, and we are further unable to say whether the gold found in the rock is the result of deposit by stream or not. The rock stands on the bank of Hunker creek, part of it under the waters of the stream, and it may be-indeed it has been suggested-that the gold found in it is only superficial, and is the result of deposit by the waters of that stream. This has yet to be determined.

Prospectors along the entire length of Stewart river predict rich finds of quartz lodes on that stream, as quartz is found in the gravel wash. A few thin veins have been found along its banks associated with black shale. It may be said, however, that no attempt has been made at quartz location. The miners now in the country, with very few exceptions, fully employ their time in search for placer diggings. They all know very well that at the present time quartz lodes are valueless, for the reason that the present freight facilities will not permit of the introduction of mining machinery, such as is required for the development, even on a small scale, of quartz or reef mines. It cannot reasonably be claimed that the vast area where this rock is found is entirely denuded of all the gold in it. If this is not the case, many of the lodes whence the placer gold was derived exist, in part at least, in the ridges between the various 
streams and gulches, and it is only a question of time and search when some of them will be found; and out of so many hundred chances it might surely be claimed that some of them will well repay development. The conditions existing there are much against easy quartz prospecting. The surface in the valleys is covered with a thick coat of moss. This again supports a dense growth of furze and shrubbery, through which we find scattered a rather thick growth of scrubby forest. Such is the vegetation until we reach altitudes of nearly 2000 feet above the river, or 2500 or 3000 feet above the level of the sea, where we come to the limit of the timber. But above this an Arctic shrubbery exists, which is almost as serious a hindrance to rock examination as what exists below, and it is only on the tops of the highest ridges, which are exposed to the fierce winds generally prevailing in that region, that we find any extensive rock exposure. Heretofore these ridges have only been visited by miners making their way from one stream to another, and as the wind blowing there is, even in the middle of summer, very often rather cool, they do not make unnecessary delays, but hurry down to more congenial temperatures and better shelter. These causes all combined have prevented, and will largely hinder in the future, all except well-organised and well-directed search. A small diamond drill plant would, I think, prove a cheap, expeditious, and satisfactory means of prospecting for quartz lodes. It can be set up anywhere, and manipulated by hand if necessary, and the core taken out will show the character of the rock, on the surface at least. Quite a large area could be successfully tested in a single season. Of course an expert would see at once, from the character of the rock, after the first foot or so had been bored, whether further attempt would be likely to prove successful or not.

Again, from the fact that all the streams in the country are covered with ice for nearly seven months in the year (from the 1st of November until the middle of May on the large streams, and from, it may be asserted, the 1st of October until the middle of May on the smaller ones), quartz mining or milling could not be economically carried on during more than five months or so in the season-that is, by the methods now employed. This will necessitate a modification of present methods, and some process of dry or semj-dry milling, as is respectfully suggested in all my reports and all my addresses on that region. How this may be accomplished time will determine. At present many methods are proposed; and as the attention of experts and those contemplating mining there has been called to these conditions, many ways have been thought out of overcoming the obstacles. How far they will succeed it is impossible at present to say. Several of them look like success, and possibly with a little experience success will be the result. When fuel is required it will be found in abundance, and at many points quite near to the quartz lodes. Coal is found at many points along the Yukon river. At some points it is exposed on the bank, at many others within a few miles of it, so that, when the necessity arises for its use, it will be a simple matter to procure it and lay it down at whatever point it may be wanted. Timber is only found in the river valleys, and there, too, quite near to the banks of the streams. A short distance away 
METEOROLOGICAL RECORD IN THE YUKON DISTRICT.

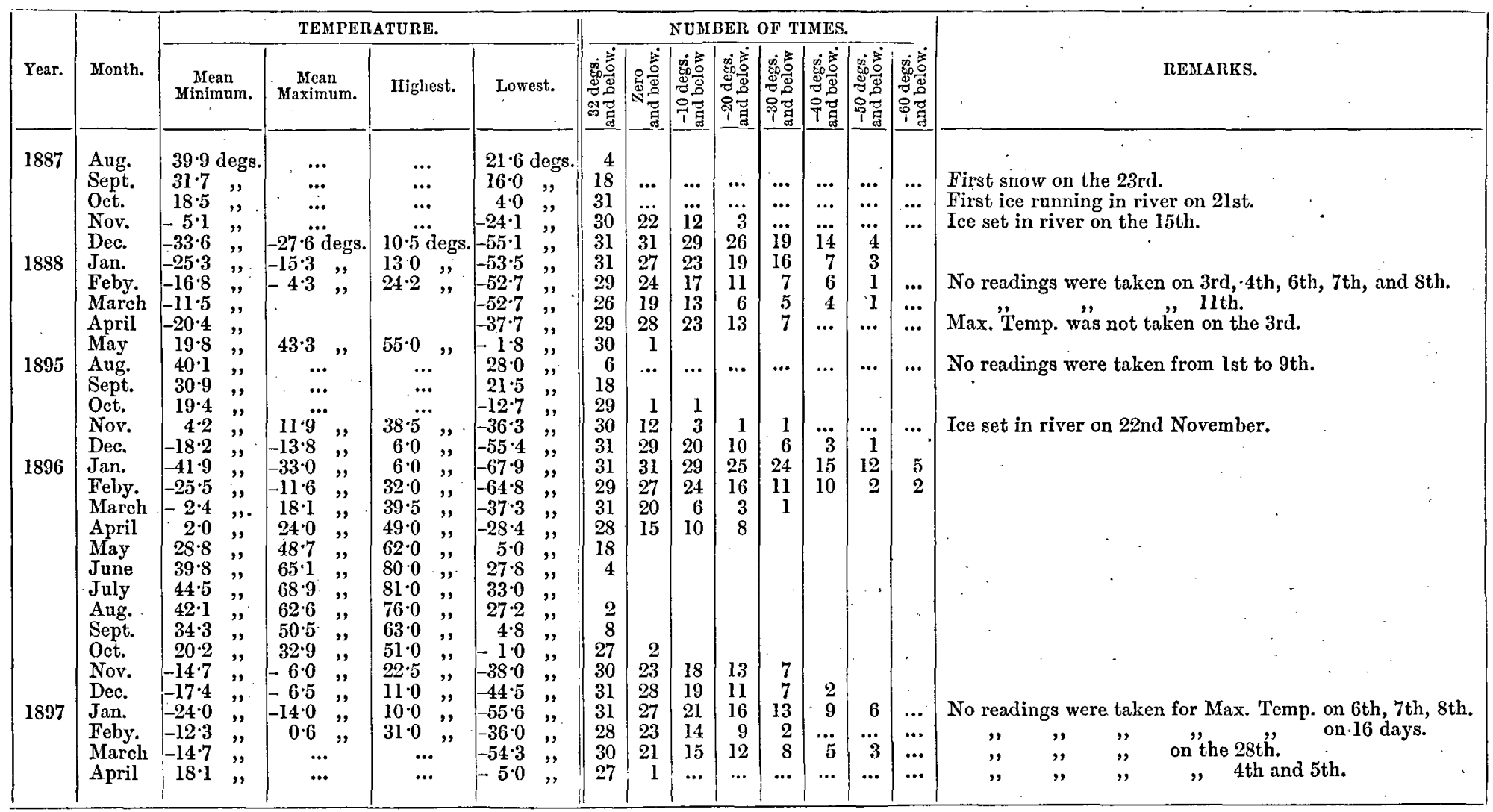


from the water the frozen ground prevents the proper development of trees. The season during which they can grow is very short, and the ground on which they grow is continually frozen. These conditions result in the growth of trees from three to six inches in diameter, which are found to be several centuries old, if we count the growth-rings, one of which generally stands for a year's growth. All commercial timber will necessarily soon become exhausted, and the sooner coal-mining is taken up the better for all concerned. This offers a safe investment to capitalists.

Other minerals are found in limited quantities in the Yukon country : galena, near Fortymile, yielding upwards of thirty oz. of silver per ton of ore; a crude form of asbestos occurs in the same vicinity; copper on White river, and traces of it at several points along the Lewes. Silver has been found in the drift on some of the streams near the head of the Lewes, and it has been declared that an extensive lode of silver ore has been found in the vicinity of Bennet lake. All these conjoined go to show that the future of that country will be much more bright and cheerful than its gloomy, inhospitable surface and long, cold, dark winters would at present indicate. There is a vast field here for a reasonably safe investment of British capital and influence; and attention is cordially invited to it by the people of Canada, not the least part of this vast Empire.

The preceding compilation from my records of temperature convey an idea of the range of temperature, and duration of the seasons. It can truthfully be said that while it is cold it is not unhealthy, nor so disagreeable as might be thought from the low thermometer readings shown.

\title{
THE TUNDRAS AND STEPPES OF PREHISTORIC EUROPE.
}

\author{
By Professor Janies Geikie, D.C.L., LL.D., F.R.S.
}

(Continued from page 294.)

(With a Map.)

\section{II. ${ }^{1}$}

IN my preceding lecture evidence was adduced to show that tundras and steppes, with their characteristic faunas, formerly existed in Central and West-central Europe. We saw that for a long time the climatic conditions of these regions must have resembled those that now obtain in Northern Siberia and the barren grounds of North America, where mosses and lichens form the prevailing growths, and arctic lemmings, hares, and foxes, the reindeer, and the musk-ox, are the common indigen-

1 A Lecture delivered before the Royal Dublin Society, 11th March 1898. 